\title{
EFFECT OF QUANTITY AND DISTRIBUTION OF RAINFALLS ON Hordeum murinum L. GROWTH AND DEVELOPMENT
}

\author{
Myrna Johnston B. ${ }^{*}$, Alfredo Olivares E. ${ }^{1}$, and Carolina Calderón E. ${ }^{1}$
}

\begin{abstract}
The growth and development of Hordeum murinum L. seeds growing with extreme pluviometric regimes in cool greenhouse conditions were evaluated. Seven treatments according to quantity and distribution of real rainfalls of the semiarid zone of the Metropolitan Region, Chile were applied: rainy-late, normal-late, dry-early, rainy-normal, normal-early and dry-late, plus a reference without water stress, at $2 / 3$ field capacity. The experimental design was randomized complete blocks with five replicate pots. Seeds produced in the last year were sown in pots with disinfected soil leaving the more uniform plants after emergence. Evaluations were made of phytomass production, spearing shoots of roots, the quantity of floral stems and seeds, their total weight and the proportion of seed annex structures, and the viability and germination capacity of seeds. The life cycle of dry years was shortest and with the least dry shoot matter production, the rainy-normal and normal-late years had similar dry root matter production, therefore the most important factor was rainfall distribution. All the reproductive growth values were lower than the reference. There was no seed production in both distributions of dry years and in the normal-early. There were only differences in late distributions, there were no differences among treatments in seed quality. Thus, $H$. murinum uses its resources principally for seed production and late distributions determined seed production.
\end{abstract}

Key words: pluviometric regime, reproductive efficiency, naturalized poacea.

\section{INTRODUCTION}

Annual pasture grasses of the Mediterranean climate of the semi-arid zone of Chile represent the main source of forage for cattle production in areas subjected to water deficits. The magnitude, floral diversity and persistence of the species that make up these ecosystems, as well as the richness of the seed bank in the soil, depend in large measure on the environmental conditions of the location. The phenology and productivity of the species present are regulated by diverse factors, among them are notably the availability of water, which determines the beginning of the life cycle, and temperature, which affects the growth velocity and development of each species. The combination of scarce water resources and high temperatures determines the end of the cycle of annual winter species whose seeds germinate and develop in spring (Castellaro and Squella, 2006). The reproductive stage that precedes the end of the cycle is

${ }^{1}$ Universidad de Chile, Facultad de Ciencias Agronómicas, Casilla 1004, Santiago, Chile.

*Corresponding author (mjohnsto@uchile.cl).

Received: 22 January 2008.

Accepted: 01 August 2008. vital in the persistence of terophytes, determining the quantity and quality of seeds that are produced (Johnston et al., 2005).

It has been demonstrated that the production and quality of seeds in Bromus berteroanus Colla (Olivares et al., 2006) and Erodium moschatum (L) L'Her. (Olivares et al., 2004) are strongly determined by precipitation during the reproductive period, given that this determines water availability during the fruiting period. Dry matter (DM) production in this species also depends on the distribution of precipitation and consequently could indirectly affect reproductive parameters through the number of flower stems induced and the provision of carbohydrates assimilated by these (Johnston et al., 2003).

Pluviometric regimes in Mediterranean zones are characterized by high variability in rainfall in both distribution and total levels, because of which native or naturalized species must modify their growth and development, changing, for example, the duration of the periods from emergence to establishment, or the growth rate (Olivares et al., 1998). Acuña (1978) in a pioneering work, simulated pluviometric regimes in situ and determined that DM production of annual pasture in a Mediterranean climate increases in those years with 
normal total precipitation, or rainy years, and can also increase or decrease according to the type of distribution of rainfall over the year.

Some seeds of annual species in semi-arid zones only germinate if the level of rainfall is sufficient for the plants to complete this stage and exceed $96 \mathrm{~h}$ of hydration. The subsequent growth of these plants will depend on the timing and level of rainfall and the soil water potential (Jara et al., 2006; Castellano and Squella, 2006). Germination and emergence respond to precipitation levels close to or higher than $20 \mathrm{~mm}$ in a single rainfall or accumulated in two weeks (Johnston et al., 1998). Rainfall levels in Chile of around $10 \mathrm{~mm}$ can be effective for naturalized plants with superficial roots; similar rainfall values were found by Volis (2007) to initiate germination found in Hordeum spontaneum Koch. and Avena sterilis L. in Israel. On the other hand, higher precipitation levels than these are important for deep-rooting native Chilean species (Gutiérrez, 1993).

As well, it has been established that seed weight is important, in that a greater initial quantity of nutrients generates seedlings of greater vigor, thus assuring a better establishment of the plant and allowing for higher production of seeds (Lorenzetti, 1993). It has been observed that seed weight in ryegrass (Lolium perenne L.) is highly variable, depending on climatic conditions under which the seeds develop. As well, climate influences the weight of ovums until anthesis, the moment at which the partition of assimilates is determined (Warringa et al., 1998).

In relation to the availability of water, Kokubun et al. (2001) determined that soya plants submitted to water stress produce a lower number of seeds owing to a reduction in photosynthesis; if the deficit occurs during flowering, there is a lower number of assimilates that go to floral structures and consequently there is a smaller number of floral abortions due to damage to the pistils or stamens.

In a study on the effects of pluviometric regimes on the behavior of $B$. berteroanus Colla, one of the most abundant species and of greater forage potential in annual pastures in semi-arid Mediterranean climates, the premise was tested that seed growth and production improved in years with a late distribution of rainfall, whether rainy or normal, and with the dry-early years (Johnston et al., 2005). It can be considered that not only is the quantity of available water important, but also rainfall distribution. Thus, even though there may be less available water in the environment, if this condition is accompanied by other favorable conditions (light and temperature) growth is favored.

Hordeum murinum, one of the most common species in semi-arid Mediterranean ecosystems, shows a high rate of initial growth, has better adaptive advantages in the context of moderate water deficit and rapidly reaches a seedling size that competes more effectively with the majority of terophytes of the semi-arid Mediterranean range (Olivares et al., 1997).

In accordance with this information, the hypothesis is proposed that the quantity and distribution of precipitation not only influences the growth and development of $H$. murinum, but also has direct effects on the quantity and quality of seeds produced.

Consequently, the general objective of this work was to study the vegetative and reproductive growth of Hordeum murinum subjected to different simulated pluviometric regimes in cool greenhouse conditions and determine the production and quality of the seeds of these plants.

\section{MATERIALS AND METHODS}

Thirty-five (35) black polyethylene pots were kept under cool greenhouse conditions (without heating), with average temperatures between $15^{\circ}$ and $26^{\circ}$ and mean relative humidity between $73 \%$ and $64 \%$. The pots were $50 \mathrm{~cm}$ deep and with a diameter of $13 \mathrm{~cm}$, with $90 \%$ of soil previously treated with bromomethane to activate existing seeds and subsequently sieved at $5 \mathrm{~mm}$, plus $10 \%$ of poliestirene spheres of the same diameter. Ten seeds of Hordeum murinum (synonymous with Critesion murinum (A. Löve) were planted in each pot. The seeds had been collected at the Agricultural Experimental Station of the

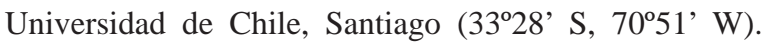
The largest seeds filled with grain were selected, using the most uniform. Seeding was carried out in March in soil with a humidity of $22 \%$ dry base weight prior to the beginning of the rains in all of the treatments. Once the simulated rainfalls that corresponded to each treatment began, the number of seedlings per pot was reduced to the five most vigorous.

Given that $H$. murinum and $B$. berteroanus coexist in the natural pasture of the semi-arid Mediterranean climate, the pluviometric regimes were used that had presented positive $(+)$ or negative effects (-) in the production of B. berteroanus (Olivares et al., 2006). The amount and timing of the application of precipitation in each treatment were made in accordance to the selected year (Figure 1); the first effective rainfall was considered as the beginning of the period and the following applications were made according to the calendar of real precipitation for the selected year (Gutiérrez, 2003). As well, a reference treatment without water restriction was maintained at $2 / 3$ of field capacity, adding water in quantities determined by the difference in the weight of the pots in relation to the initial content that was equivalent to $50 \mathrm{~mm}$ of rain. The soil water content was calibrated on the basis of the data 
obtained by Olivares et al. (2004) for the same type of soil, from the Cuesta Barriga series (Typic Haploxerolls), with which the soil weight was determined at field capacity (100\% of available water). Rainfalls were applied according to the calendar of each year selected using a serum dispenser that simulates drip irrigation, allowing that the corresponding quantity of water was applied over $24 \mathrm{~h}$.

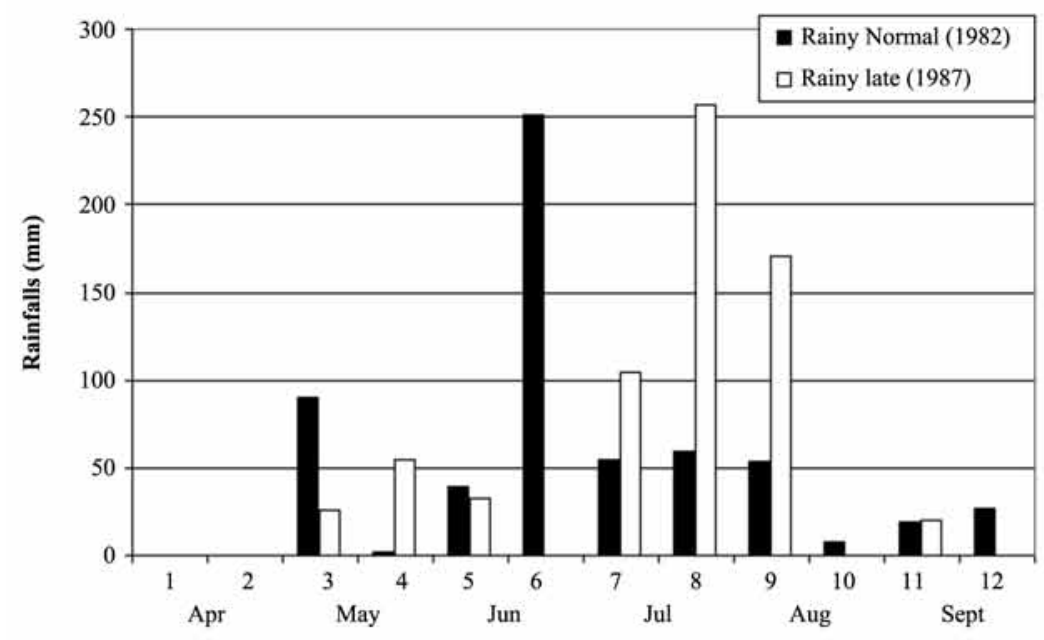

Period (fifteens)

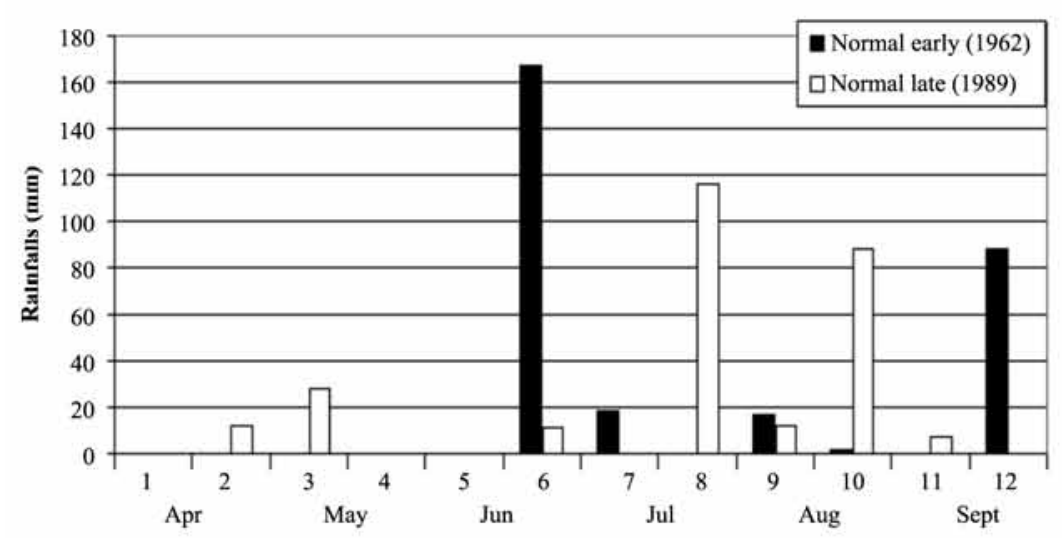

Period (fifteens)

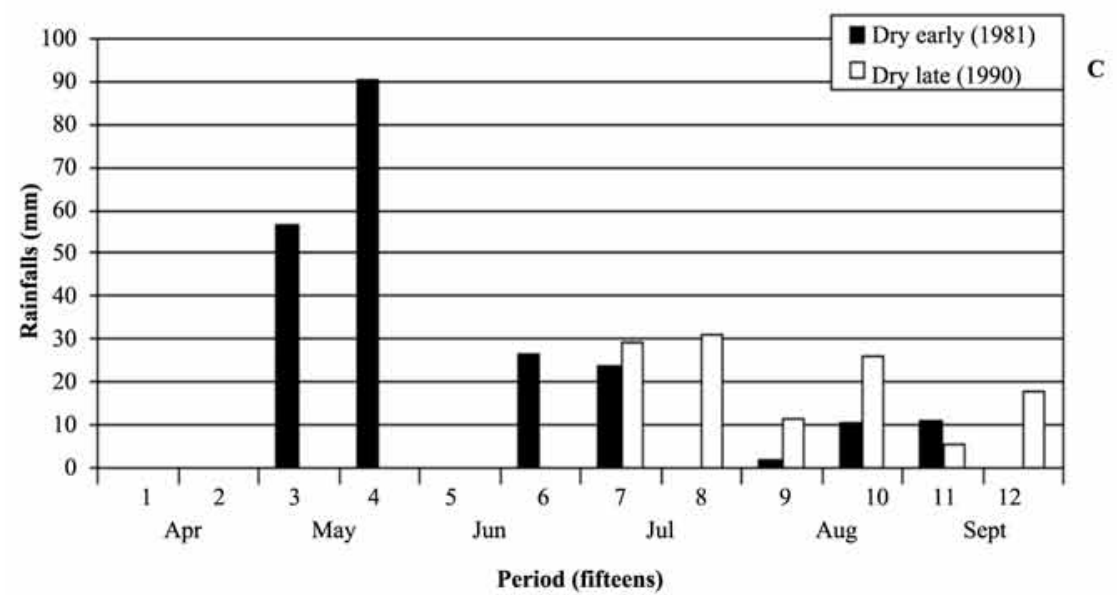

Figure 1. Rainfall distribution (mean of $\mathbf{1 5}$ days) of different selected pluviometric regimes: A) rainy years, B) normal years, C) dry years. 
The treatments used were: Ll-n, rainy year with normal distribution (-) with a total of $628.0 \mathrm{~mm}$ (year 1982); Ll-ta, rainy year with late distribution $(+)$ with a total of $670.6 \mathrm{~mm}$ (year 1987); N-Te, normal year with early distribution (-) with a total of $257.5 \mathrm{~mm}$ (year 1962); $\mathrm{N}$-ta normal year normal with late distribution $(+)$ with a total of $281.4 \mathrm{~mm}$ (year 1989); S-te, dry year with early distribution (+) with a total of $225.2 \mathrm{~mm}$ (year 1981); S-ta, dry year with late distribution (-)with a total of $157.1 \mathrm{~mm}$ (year 1990); and the reference without water restriction (control).

\section{Aerial and root phytomass production}

This was assessed through the determination of phytomass produced in shoots and roots at the end of the annual cycle and was expressed as the average g DM per pot. To obtain the roots, all the soil from each pot was placed in a mesh that was submerged in water for $24 \mathrm{~h}$. The roots were then separated with a fine rain of water over a screen. The material collected was dried in a forced air oven at $70^{\circ} \mathrm{C}$ for $48 \mathrm{~h}$ and was finally weighed to obtain the DM of each part. With these values the root/shoot ratio was calculated.

\section{Production of reproductive phytomass}

Reproductive phytomass was evaluated at the end of the cycle by counting the number of floral stems once the seeds matured; the quantity of seeds at the harvest date (mature ear) and the total weight of seeds per plant. Seed quality was evaluated by the proportion of palea, lemma and arista (annexes) of seeds per plant and per fruit; by the fullness of seeds by separating well-developed seeds with abundant reserves (full) from those that were not developed (empty); by the weight of 100 seeds as an estimation of size; by viability and germinative capacity. For the latter, germinative tests were conducted with 25 seeds on filter paper and water in a Petri capsule, with eight repetitions per treatment and following the international guidelines for seed tests (ISTA, 2007). To determine the viability of seeds that did not germinate, the seeds were submerged in a solution at $1 \%$ of chloride de 2,3,5-triphenyl-tetrazolium for $24 \mathrm{~h}$ at $25{ }^{\circ} \mathrm{C}$ in darkness, measuring reddening in accordance with the ISTA (2007).

The reproductive index (RI) was calculated for each treatment, which is the ratio between the total weight of disseminules and vegetative phytomass per plant, and the reproductive efficiency index (REI), which is the ratio between the number of disseminules per plant and its phytomass weight (Aronson et al., 1993).

\section{Phenology}

The development of the plants was observed and records were made of the main phenological states: emergence, foliation, tillering, elongation of the stem (a sign of floral induction), flowering, formation and maturing of fruit and senescence of the leaves. Each phenophase was registered when it was present in $50 \%$ of the plants in each treatment.

An experimental design with completely random blocks was used, with five replications per treatment. The experimental unit was a pot with five plants. A variance analysis (ANDEVA) was conducted for two ways for each independent variable. When the variation was significant, the means of the treatments were compared using the Newman-Keuls test (Montgomery, 1991). The statistical package Minitab (2000), version 13 was used, with a level of significance of 0.05 .

The analysis of the residuals of the analyzed variable (except percentages) satisfied the suppositions of normality and homogeneity of variances, because of which the usual parametric tests to compare treatments were carried out. In the case of percentages, the data was previously transformed to Bliss degrees.

\section{RESULTS AND DISCUSSION}

The ANDEVA carried out for each variable studied showed in the majority of the cases that there were major differences between the reference treatment without water restrictions and the treatments with different degrees of water deficit (pluviometric regimes), because of which it was decided to conduct a second analysis excluding only the reference in order to compare the behavior of plants subjected to the studied pluviometric regimes.

\section{Production of aerial and root phytomass}

The rainy-late year reached an average value of aerial DM (ADM) per plant (Figure 2) similar to that of the reference treatment (Table 1). The general tendency showed that at lower availability of water the accumulation of ADM decreased; because of which the dry years had the lowest production, followed by the normal-early year. The importance of distribution is notable, given that production in the normal-late year does not differ from that of the rainy-normal year.

The fact that $H$. murinum can express its growth potential in frequent rainy-late year in the dry interior, given production of ADM was similar to the reference treatment without water restriction, suggests that the pluviometric regime could explain in part the success of this species in this type of year. Other poaceae, such as $B$. berteroanus, which co-exists with $H$. murinum in the pasture, does not reach the same growth potential as it reached without water restriction with any of the prototypes of pluviometric regimes detected in the zone (Olivares et al., 2006). 
Table 1. Growth values of Hordeum murinum without water stress (reference treatment).

\begin{tabular}{lr}
\hline Variable & Values \\
\hline Dry aerial material, g plant $^{-1}$ & 2.63 \\
Dry root material, g plant $^{1}$ & 1.35 \\
Root/shoot ratio & 0.51 \\
Quantity of floral stems & 11.20 \\
Total quantity of seeds & 250.70 \\
Fruit weight, mg & 1679.00 \\
Seed weight, mg & 77.00 \\
Quantity of full seeds per plant & 182.20 \\
Quantity of empty seeds per plant & 68.49 \\
Weight of annexes, mg & 914.00 \\
Percentage of germination & 96.00 \\
Percentage of viability & 98.00 \\
Estimated size, mm & 5.59 \\
Reproductive efficiency index (REI) & 0.42 \\
Reproductive index (RI) & 62.98 \\
\hline
\end{tabular}

Lower production in dry years could be because of reduced foliar area when there are conditions of water deficit, owing to the fundamental role of water in cellular expansion (González and Páez, 1995). With normal precipitation, early distribution exercises a negative effect, such that there were no differences in the production of $\mathrm{ADM}$ in comparison to years with low precipitation with any distribution. From this, it can be deduced that late distribution in rainy years is positive and early distribution in normal years is negative, such that distribution can alter the effect expected based on the total quantity of rainfall. The different timing of rainfalls generated by each distribution results in plant growth occurring at different periods, which can imply more or less thermal and light conditions. This can explain the results obtained and also what is often observed in the field (Castellaro and Squella, 2006).

The DM of the roots (RDM) was less sensitive to the quantity and distribution of precipitation given that higher production was obtained only in the rainy-late year, and the rainy-normal year did not present differences with the normal-late year and dry years with any distribution (Figure 2). The quantity of water and the timing of rains also influenced the root growth of this species, such that while there was a similar behavior among most of the years studied, the most favorable was rainy-late, which produced a quantity of DM equivalent to that produced by the reference without water restriction (Table 1). The normal-late year and the rainy-normal showed similar behaviors despite the major differences in the total amount of rainfall.

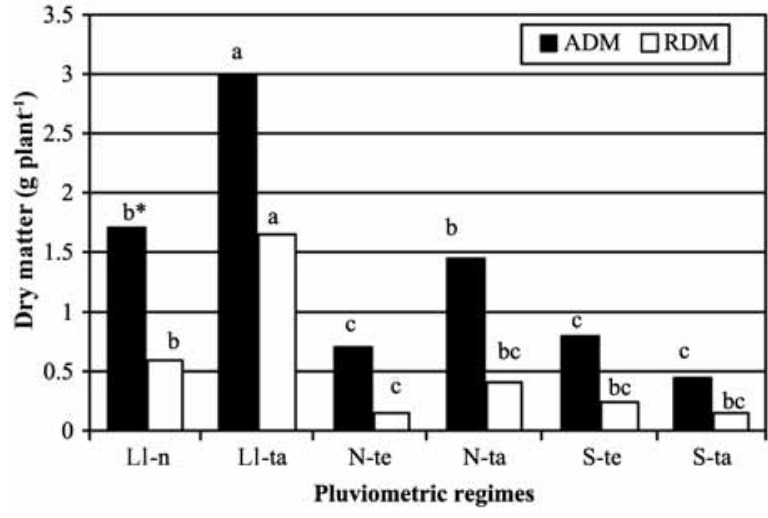

* Different letters over columns of the same color indicate significant differences among treatments $(\mathrm{P} \leq 0.05)$.

Figure 2. Shoot (ADM) and root (RDM) dry matter of Hordeum murinum plants according to rainfall levels and distribution. Ll-n rainy normal, Ll-ta rainy late, $\mathrm{N}$-te normal early, $\mathrm{N}$-ta normal late, S-te dry early, Sta dry late.

Greater root growth in the rainy-late year corroborates the results obtained with Bromus pictus Hook submitted to intense water stress, where the reduction in shoot growth did not significantly alter root growth (Rotundo et al., 2006). Other species also respond to stress by increasing the proportion of assimilates directed to the roots, which allows for diversifying radical growth and thus increase available water for the plant (Huang and Fry, 1998). This explains the similarity of behavior observed in the production of RDM in the different years, with the exception of the rainy-late year. Another work with Festuca arundinacea (Huang and Gao, 2000) showed that a moderate stress reduced the length and production of RDM, increasing on the other hand the development of radical hairs with which a greater provision of water is achieved. In studies on the emergence of species of the annual range in the semi-arid Mediterranean zone, it has been demonstrated that $H$. murinum is the most tolerant to a reduction in soil moisture (Olivares et al., 1997). Thus, the results indicate a greater capacity of $H$. murinum to obtain water, or in effect, less sensitivity to water stress.

On the other hand, the fact that a normal-late year has similar production of DM to that of a rainy-normal year, despite the differences in the total quantity of precipitation supports the argument that the distribution of precipitation is very important in the production of phytomass. In this regard, González and Páez (1995) point out that the response to water stress depends on the species and the state of development of the plant at the time when rainfall occurs. 
The root/shoot ratio shows similar values among the pluviometric regimes ( 0.28 to 0.55 ), with the exception of the N-te, which was significantly higher (1.64); the value of the reference treatment was the same as that the rainynormal year. This similarity of the ratio in the majority of the conditions studied indicates that normally there would be a greater proportion of resources destined to the shoots than to the roots and that $H$. murinum is capable of adjusting the proportions of phytomass assigned to these structures. The high values of the normal-early year are due to the fact that these plants do not complete their cycle or produce fruits, because of which all of their resources are directed to the growth of shoots. Li et al. (2008) points out that climatic variables explain around $50 \%$ of the changes in the root/shoot ratio of plants in non-degraded pastures.

\section{Reproductive biomass production}

It should be noted that the dry years, with early and late distribution, and the normal-early year did not reach reproductive development; consequently they are not included in the respective analysis. All the variables on the quantity of measured reproductive growth that completed their reproductive cycle (Table 2) had lower values than those obtained from the reference treatment (Table 1), which would indicate that any water restriction reduces the reproductive structures produced by $H$. murinum $\mathrm{L}$. The behavior was similar in rainy years with both late and normal distribution, while in comparison to the late distributions with different quantities of total precipitation, it was demonstrated that there are differences in all the measured variables, with the normal year being higher.

Kokubun et al. (2001) observed that a water deficit in the flowering phase of soya (Glycine max (L.) Merr.) reduced the contribution of assimilates to floral structures, determining a higher number of floral abortions and damage to pistils and stamens. Something similar occurred in $H$. murinum in those treatments that did not produce fruits, the similar results obtained in the rainy years indicate that the changes could be attributable, on the one hand, to factor related to the production and transfer of assimilates, and on the other hand, to the growth and development of seeds, rather than a change in the potential number of seed sites, which coincides with the results of other works (Johnston et al., 2003).

Upon analyzing seed quality, it was observed that the values of the normal-late year were the highest in the number of seeds and weight of annexes (Table 2); in the case of rainy years, although they did not differ among them, they tend to produce more empty seeds and with higher weight of annexes in the late distribution. Considering the relative proportion of annexes and base seeds in relation to total fruit weight (Figure 3) it was demonstrated that the late distributions present higher proportions of annexes, with those from the normallate year being highest. Nevertheless, in terms of the proportion of seeds, the rainy-normal year had the highest values the normal-late year had the lowest. In the plants without water restriction, there was a high production of seeds (Table 1 ) with $27 \%$ of empty seeds.

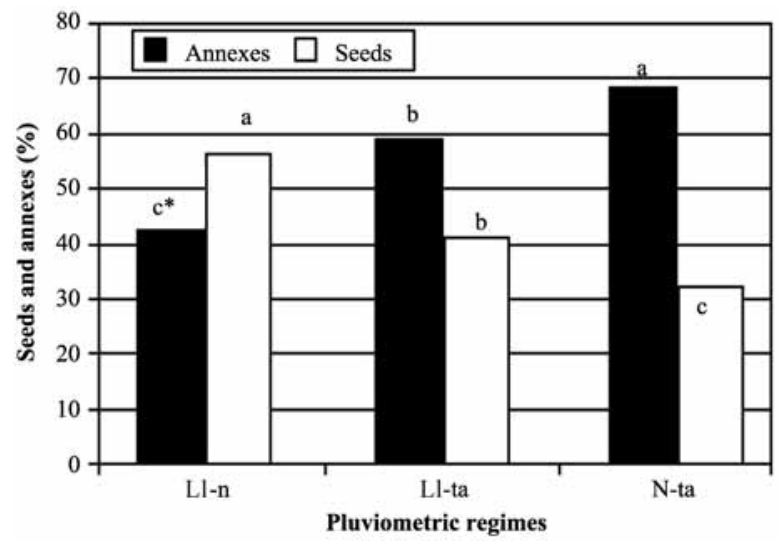

* Different letters over columns of the same color indicate significant differences among treatments $(\mathrm{P} \leq 0.05)$.

Figure 3. Annex and seed percentage in relation to total fruit weight from Hordeum murinum according to rainfall levels and distribution Ll-n rainy normal, LIta rainy late, $\mathrm{N}$-ta normal late.

Table 2. Phytomass reproductive components: floral stem (FS), total seed (TS), full and empty seeds number; fruit (seed plus annexes), seed (S) and annex weight of Hordeum murinum according to amount and distribution of annual rainfalls.

\begin{tabular}{llcccccc}
\hline Treatments & FS & $\begin{array}{c}\text { Fruit } \\
\text { weight }\end{array}$ & TS & S & $\begin{array}{c}\text { Full } \\
\text { seeds }\end{array}$ & $\begin{array}{c}\text { Empty } \\
\text { seeds }\end{array}$ & $\begin{array}{c}\text { Peso } \\
\text { annexes }\end{array}$ \\
\hline & $\mathrm{N}^{\mathrm{o}}$ & $\mathrm{mg}$ & $\mathrm{N}^{\mathrm{o}}$ & $\mathrm{mg}$ & $\mathrm{N}^{\mathrm{o}}$ & $\mathrm{N}^{\mathrm{o}}$ & $\mathrm{mg}$ \\
Rainy-normal (Ll-n) & $1.1 \mathrm{~b}^{*}$ & $58 \mathrm{~b}$ & $16.7 \mathrm{~b}$ & $33 \mathrm{~b}$ & $11.6 \mathrm{~b}$ & $5.5 \mathrm{~b}$ & $25 \mathrm{~b}$ \\
Rainy-late (Ll-ta) & $0.9 \mathrm{~b}$ & $88 \mathrm{~b}$ & $19.7 \mathrm{~b}$ & $37 \mathrm{~b}$ & $11.7 \mathrm{~b}$ & $7.9 \mathrm{~b}$ & $51 \mathrm{~b}$ \\
Normal-late (N-ta) & $1.9 \mathrm{a}$ & $210 \mathrm{a}$ & $45.0 \mathrm{a}$ & $72 \mathrm{a}$ & $30.9 \mathrm{a}$ & $14.1 \mathrm{a}$ & $142 \mathrm{a}$ \\
\hline
\end{tabular}

* Different letters in the column indicate significant differences among treatments $(\mathrm{P} \leq 0.05)$. 
Precipitation and low temperatures during flowering in populations of Hordeum spontaneum and $H$. vulgare determined positive correlations between the crosspollination rate and annual average precipitation and negative correlations between the former and cold temperatures during flowering (Abdel Ghani et al., 2002). On the other hand, according to Egli (2004) water stress during the seed development of oats and other species cuts this period and reduces production. As well, water stress accelerates foliar senescence in Avena sativa L. It can then be considered that the normal-late year provides the most favorable conditions for the growth of reproductive structures (fruits), but rainy years favor the movement of assimilates to the seeds.

The pluviometric regime did not affect the capacity for germination, total viability or the estimated seed size (Table 3), and their values did not differ from those presented by the treatment without water restriction. It could be concluded with this that the persistence of the species is assured under unfavorable conditions as argued by Abdel Ghani et al. (2002) for Hordeum spontaneum and $H$. vulgare. Similar results were obtained by Herrera et al. (2008) in Chloris cucullata and C. subdolichostachys where the percentage of full and dormant seeds changed among years with different distributions of precipitation, but without altering viability.

It has been established that once the number of fruiting sites is fixed, water availability will determine the fullness of seeds, both in terms of production and transportation of new assimilates and the transfer of assimilates from reserve (Johnston et al., 2003). This explains the fact that the reference treatment had the lowest proportion of empty seeds, that the proportion of seeds was higher in the normal rainy year, that the proportion of annexes was higher in late years and that all the seeds produced presented high percentages of germination.

The calculated indicators of reproductive growth (Table 3) show that the pluviometric regimes that complete this phase presented changes in the assignment of resources for the production of disseminules. Thus, the normal-late year was significantly more favorable with the highest indices, both in reproductive efficiency (REI) and the reproductive index (RI), which indicates that a greater quantity of assimilates are destined to form seeds than in the other treatments, with the exception of the reference, which is also reflected in values of the quantity and weight of the seeds obtained (Table 2).

Works with $H$. spontaneum and A. sterilis (Volis, 2007) using gradients of aridity that included quantity and distribution of precipitation showed that increasing aridity reduced the maturation time of the seeds and that there was a negative correlation between the size and number of seeds, a tendency similar to what was shown in the normal-late year.

All of this shows the different strategies that $H$. murinum uses to assign its resources to the diverse components of reproductive growth according to the pluviometric regime that is present, and consequently allows for understanding not only its great productive potential but also its great plasticity, its tolerance to adverse conditions and its great capacity for persistence in the annual range of the semi-arid Mediterranean zone. Something similar was argued by Aronson et al. (1993) for some annual desert species, where changes in reproductive biomass in the context of water stress is manifested in both the number and size of seeds, which allows for survival under critical conditions.

\section{Observations of phenological development}

$H$. murinum did not complete its life cycle in the dry years and the normal-early years, while the reference treatment without a water deficit had the longest life cycle and the longest reproductive stage. In the treatments where the cycle was completed a marked separation of the vegetative phenophases was observed. The duration of this stage was similar in all the treatments (Table 4); nevertheless, it can be noted that the rainy-late year had a more prolonged emergence even though its initiation was simultaneous to the other treatments (10 days after seeding). The normal-late year presented a longer tillerage phase than the other treatments and did not have a defined foliation phase.

Table 3. Germination and viability percentage, mean seed size and values of reproductive efficiency: reproductive index (RI) and index of reproductive efficiency (REI) of Hordeum murinum according to annual rainfall amount and distribution.

\begin{tabular}{|c|c|c|c|c|c|}
\hline Treatments & Germination & Viability & Size & REI & $\mathbf{R I}$ \\
\hline & 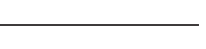 & 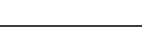 & $\mathrm{mm}$ & & \\
\hline Rainy-normal (Ll-n) & $95 a^{*}$ & $97 a$ & $5.6 a$ & $6.98 b$ & $0.03 \mathrm{~b}$ \\
\hline Rainy-late (Ll-ta) & $93 a$ & $96 a$ & $6.1 \mathrm{a}$ & $4.22 \mathrm{~b}$ & $0.02 \mathrm{~b}$ \\
\hline Normal-late (N-ta) & $98 a$ & 99a & $5.8 \mathrm{a}$ & 21.70a & $0.12 \mathrm{a}$ \\
\hline
\end{tabular}

* Different letters in the same column indicate significant differences among treatments $(\mathrm{P} \leq 0.05)$. 
Table 4. Phenological stage duration (days) of Hordeum murinum, according to annual rainfall amount and distribution.

\begin{tabular}{lrrrrrrrrr}
\hline Year & Em & Fol & Mac & Fol-til & $\begin{array}{c}\text { Stem } \\
\text { elong }\end{array}$ & Flo & Seed & Mat & Senes \\
\hline Rainy-normal & 7 & 20 & 7 & 31 & 30 & 37 & 35 & 35 & 46 \\
Rainy-late & 25 & 5 & 7 & 25 & 26 & 17 & 12 & 35 & 29 \\
Normal-early & 15 & 10 & 21 & 14 & $*$ & $*$ & $*$ & $*$ & 35 \\
Normal-late & 10 & 29 & 32 & 0 & 27 & 27 & 23 & 23 & 31 \\
Dry-early & 17 & 14 & 21 & 10 & 17 & $*$ & $*$ & $*$ & 58 \\
Dry-late & 11 & 20 & 15 & 17 & 25 & $*$ & $*$ & $*$ & 26 \\
Reference & 8 & 23 & 20 & 15 & 44 & 27 & 27 & 54 & 46 \\
\hline
\end{tabular}

* The totality of the plants did not present the phenological phases, only the beginning of the stages was evidenced.

Em: emergence, Fol: foliation, Til-tillering, Fol-til: foliation of tillerage, Stem elong: Stem elongation, Flo: flowering, Seed: seeding, Mat: maturation, Senes:senescence.

According to Egli (2004) water stress during seed development of oats and other species cuts the cycle and reduces production. It was also observed that water stress in A. sativa accelerates foliar senescence.

This species was able to express the total of its growth potential in the tested rainy years and given that its response is very similar to the reference treatment, it could indicate a greater competitive potential in relation to other species of this range, such as Bromus berteroanus Colla and Avena barbata Pott. which can only present their potential when there are no water restrictions (Olivares et al., 2006; Castellaro and Squella, 2006). Nevertheless, in exceptionally rainy years, these two species have advantages given their potential for growth and development has been higher than what is obtained with pluviometric regimes typical of the area.

The duration of the reproductive stage, considered from stem elongation, was the most affected by the pluviometric regimes and the phenophases showed diverse degrees of superimposition in all the treatments. The year normal-late year had the shortest total duration of the cycle, suggesting that water availability is a determinant of this duration (Table 4).

In general it was observed that without water restriction the species extends its cycle and has a considerably longer seed maturation phase than with the other treatments. The stem elongation phase was also longer and the senescence phase was one of the latest to initiate.

The alterations observed in the duration of the phenophases seems to be directly linked to both the quantity and timing of rainfalls (Figure 1). Thus, the prolongation of the emergence period of the rainy-late year is explained by the fact that between May and June there was little availability of water, which, added to the low winter temperatures, impeded the initial development of the root. On the other hand, maximum precipitation occurring in August shortened foliation in the normal distribution and prolonged this phase in rainy-late distribution because of a condition of hypoxia or anoxia in the soil, as has been shown in other species (Drew, 1997).

Although the duration of the total life cycles were similar, the rainy years showed different durations of the phenophases in accordance with the distribution of rainfall, particularly in emergence, foliation, flowering, seed formation and senescence. This could be because the water deficit was presented in one case at the beginning and the other at the end of the pluviometric cycle, affecting different development stages in the two treatments. The dry years tested, independent of the distribution, did not allow for reaching the reproductive stage, thus the amount of precipitation will alter the duration of the phases, shortening or extending them according to the quantity of available water.

Although $H$. murinum shortened its phases in the normal-late year in adaptation, it developed a longer vegetative stage in comparison to the reproductive stage, with which it would have a greater probability of generating the photosyntates that assured the higher production of seeds that was observed by Johnston et al. (2003) when this species is submitted to stress by cuts. In contrast, a lower quantity of precipitation determined that some phases were not completed, as occurred in the dry-early and dry-late years.

\section{CONCLUSIONS}

It can be concluded that:

Hordeum murinum produces a greater quantity of total dry material with more favorable water regimes in terms of the quantity of precipitation and a better distribution.

The distribution of precipitation appears to be the most important determining factor in the production of seeds of this species. 
Seed quality, expressed in the capacity to germinate and viability, is not affected by the pluviometric regime of the semi-arid Mediterranean region.

The species assigns a greater part of its reproductive resources to seed production, which gives it more potential for adaptation to distinct water conditions.

In the dry years with early or late distribution of rainfalls and early rainy years there is no possibility of re-seeding for this species.

\section{RESUMEN}

\section{Efecto delacantidady distribucióndelasprecipitaciones} en el crecimiento y desarrollo de Hordeum murinum $\mathbf{L}$.

Se evaluó el desarrollo de plantas de Hordeum murinum sometidas a regímenes pluviométricos simulados en invernadero frío. En un diseño de bloques completos al azar con cinco repeticiones, se establecieron tratamientos según cantidad y distribución de las precipitaciones reales del secano de la Región Metropolitana, Chile: lluviosotardío, normal-tardío, seco-temprano, lluvioso-normal, normal-temprano, seco-tardío y uno de referencia sin restricción hídrica. Se sembraron semillas del año en macetas con suelo desinfectado dejando cinco plántulas uniformes en tamaño y sanidad. Las lluvias simuladas se aplicaron según el calendario del año seleccionado. Se evaluó la producción de fitomasa aérea y radical, la cantidad de tallos florales, de frutos y semillas y su peso total; la proporción de anexos y el llenado de las semillas, su viabilidad y capacidad germinativa. En los años secos el ciclo vital fue más breve y hubo menor producción de materia seca aérea; en los lluvioso-normal y normal-tardío se presentó un crecimiento radical similar, insinuando que es más determinante la distribución de las precipitaciones. Todos los parámetros de crecimiento reproductivo en los regímenes usados fueron inferiores a los de referencia sin restricción hídrica. Los años secos y el normal-temprano no produjeron semillas. La calidad de semillas producidas en el resto de los tratamientos no fue afectada por los regímenes pluviométricos. Se concluye que $H$. murinum destina gran parte de sus recursos a producción de semillas sin alterar su calidad y que las distribuciones tardías son más determinantes para esta producción.

Palabras clave: régimen pluviométrico, eficiencia reproductiva, poacea naturalizada.

\section{LITERATURE CITED}

Abdel Ghani, A.H., H.K.Parziez, and H.H.Geiger . 2002. Estimation of outcrossing rate in Hordeum spontaneum and barley landraces from Jordan. Heredity 41:49-62.
Acuña, H. 1978. Relaciones entre productividad primaria y pluviometría en una pradera anual de la zona mediterránea semiárida de Chile. 60 p. Tesis Mg. Sc. Universidad de Chile, Facultad de Ciencias Agrarias y Forestales, Santiago, Chile.

Aronson, J., A. Kigel, and A. Shmida. 1993. Reproductive allocation strategies in desert and Mediterranean populations of annual plants grown with and without stress. Oecologie 93:336-342.

Castellaro, G., y F. Squella. 2006. Modelo simple de simulación para la estimación del crecimiento, fenología y balance hídrico de praderas anuales de clima mediterráneo. Agric. Téc. (Chile) 66:271-282.

Drew, M. 1997. Oxygen deficiency and root metabolism: Injury and acclimatation under hypoxia and anoxia. Annu. Rev. Plant Physiol. Mol. Biol. 48:223-250.

Egli, D.B. 2004. Seed- fill duration and yield of grain crops, Advances in Agronomy. 83:243-278.

González, M., y A. Páez. 1995. Efecto del déficit hídrico aplicado durante diferentes etapas de desarrollo de Panicum maximun Jacq. Maracaibo, Venezuela, Rey. Facultad Agronomía (Luz) 12:79-93. Available at http://www.revfacagronluz.org.ve/v13_1/v131z008. html (Accessed 11 January 2003).

Gutiérrez, J. 1993. The effect of water, nitrogen and human-induced desertification on the structure of ephemeral plant communities in the Chilean coast desert. Rev. Chil. Hist. Nat. 66:337-344.

Herrera, F., W.R. Ocumpaugh, J.A. Ortega,J.Lloyd-Reilley, G.A. Rasmussen, and S. Maher. 2008. Environmental influences on seed quality of windmillgrass ecotypes in South Texas. Agronomy J. 10:1255-1210.

Huang, B., and H. Gao. 2000. Root physiological characteristics associated with drought resistance in tall fescue cultivars. Crop Sci. 40:196-203.

Huang, B., and J. Fry. 1998. Root anatomical, physiological and morphological responses to drought stress for tall fescue cultivars. Crop Sci. 38:1017-1022.

ISTA. 2007. International Rules for Seed Testing. Version 2007. International Seed Testing Association, Switzerland.

Jara, P.A., G. Arancio, R. Moreno, y M. Carmona. 2006. Factores abióticos que influencian la germinación de seis especies herbáceas de la zona árida de Chile. Rev. Chil. Hist. Nat. 79:309-320.

Johnston, M., A. Olivares, V. García de Cortazar, y X. Contreras. 1998. El banco de semillas del suelo y su respuesta a regímenes pluviométricos simulados. I. Comunidad de terófitas del Mediterráneo semiárido. Av. Prod. Anim. 23:45-54. 
Johnston, M., A. Olivares, y J. Laura. 2003. Estrategias reproductivas de terófitas del Mediterráneo semiárido como respuesta a tratamientos de corte. Phyton 64:267-280.

Johnston, M., A. Olivares, y C. Gutiérrez. 2005. Efecto del régimen pluviométrico de la Región Metropolitana en la producción y calidad de semillas de Bromus berteroanus Collar. Agro Sur 33:01-08.

Kokubun, M., S. Shimada, and M. Takahashi. 2001. Flower abortion caused by preanthesis water deficit is not attributed to impairment of pollen in soybean. Crop Sci. 41:1517-1521.

Li, Y., T. Luo, and Q. Lu. 2008. Plant height as a simple predictor of the root to shoot ratio: Evidence from alpine grasslands on Tibetan Plateau. J. Veget. Sci. 19:245-252.

Lorenzetti, F. 1993. Achieving potential herbage seed yield in species of temperate regions. Vol. 2. p. 1621-1628. Proceedings XVII International Grassland Congress, Palmerston North, Hamilton, Lincoln, New Zealand. International Grassland Association. Palmerston North, New Zealand.

Minitab Inc. 2000. Meet Minitab: Release 13 for Windows ${ }^{\circledR}$ 95/98/2000 and Windows NTTM. Minitab, USA.

Montgomery, D. 1991. Diseño y análisis de experimentos. 589 p. Iberoamericana, Madrid, España.
Olivares, A., M. Johnston, y C. Beck. 1997. Emergencia de especies de la pradera natural de tipo mediterráneo en relación con la humedad del suelo. Av. Prod. Anim. 22:23-29.

Olivares, A., M. Johnston, y X. Contreras. 1998. Régimen pluviométrico del secano interior de la Región Metropolitana. Av. Prod. Anim. 23:35-43.

Olivares, A., M. Johnston, y E. Salas. 2004. Distribución de la precipitación y producción de semillas de alfilerillo, Erodium moschatum (L.) L’Hér. Agric. Téc. (Chile) 64:251-263.

Olivares. A., M. Johnston y C. Gutiérrez. 2006. Crecimiento y desarrollo de Bromus berteroanus Colla. sometido a diferentes regímenes pluviométricos. Agric. Téc. (Chile) 66:166-173.

Rotundo, L., P. A. Cipriotti, and P. E. Gundel. 2006. Morphological and growth responses to water stress of two sub-populations of Bromus pictus from soils with contrasting water availability. Rev. Chil. Hist. Nat. 79:65-74.

Volis, S. 2007. Correlated patterns of variation in phenology and seed production in populations of two annual grasses along an aridity gradient. Evol. Ecol. 21:381-393.

Warringa, J., R. De Viseer, and A. Kreuzer. 1998. Seed weight in Lolium perenne as affected by interactions among seeds within the inflorescence. Ann. Bot. (London) 82:835-841. 